Doi: $\underline{\mathrm{dx} . \text { doi.org/10.17921/2525-5320.2016.270-271 }}$

\title{
PRONATEC: FORMAÇÃO E EMPREGABILIDADE
}

\author{
Adriano Rosa Alves* - UNOPAR \\ Claudir Sales de Lima* - UNOPAR \\ Maria Aparecida dos Reis* - UNOPAR
}

Palavras-chave: Pronatec. Formação. Empregabilidade.

\section{INTRODUÇÃO}

Para Saviani (2007) é o trabalho que defini a essência humana. Isso significa que não é possível ao homem viver sem trabalhar. Já que o homem não tem sua existência garantida pela natureza, sem agir sobre ela, transformando-a e adequando-a às suas necessidades, o homem perece. Assim, diante de uma sociedade na qual impera a competitividade e a evolução tecnológica nada mais coerente do que investigar quais os frutos oriundos da formação técnica profissional e também, a influência das disciplinas interativas na composição do conhecimento dos alunos.

Analisar a normatização do PRONATEC, à qualidade das disciplinas interativas e o grau de empregabilidade e promoções profissionais frutos da formação no Pronatec.

\section{MATERIAL E MÉTODOS}

O método abordado para realizar a presente pesquisa fora o dialético, pois, segundo Vianna (2001), o método dialético possibilita a interpretação dinâmica da realidade e é influenciado pelos aspectos políticos, econômicos e culturais. Quanto à abordagem para construção desta pesquisa, sua estruturação fora baseada na metodologia mista, envolvendo as abordagens qualitativa e quantitativa (CRESWELL, 2007). Após a aplicação dos questionários eletrônicos, tendo como sujeitos 61 alunos dos Cursos Técnicos do Pronatec, descrevemos cada etapa e analisamos à luz dos pressupostos teóricos de CZERNISZ (2010), FRIGOTTO

\footnotetext{
*E-mail: adriano.alves@kroton.com.br

*E-mail: claudir.lima@sercomtel.com.br

*E-mail: mariareismt@hotmail.com
} 
(2011), KENSKI (2012), Moran (2013) e demais autores. As etapas da pesquisa foram: (1) elencar os autores que corroboravam com o tema proposto; (2) elaborar um instrumento de pesquisa para coleta dos dados a serem analisados; (3) aplicação dos questionários; (4) análise de artigos, livros e reportagens sobre o tema proposto; (5) análise dos resultados obtidos através dos sujeitos.

\section{RESULTADOS E DISCUSSÃO}

A análise dos resultados nos apontou que $49 \%$ dos alunos formandos continuam à procura de um trabalho. $22 \%$ dos alunos permaneceram no mesmo status onde atuam profissionalmente, sem qualquer promoção ou elevação salarial após a conclusão do curso. Tais resultados nos apontam que os objetivos do Pronatec, em nossa localização, não foram atingidos. Vale ressaltar que estamos passando por um período de recessão e, mesmo com a formação técnica, as oportunidades estão escassas.

\section{CONCLUSÃO}

Os resultados indicaram que a maioria dos alunos buscaram algum curso do PRONATEC para obter, após sua formação, novas oportunidades no mercado de trabalho, bem como, a insatisfação pela oferta de disciplinas interativas utilizadas nos cursos ofertados.

\section{REFERÊNCIAS}

CZERNISZ, E.C.S. Um novo ensino médio e profissional brasileiro ou a reedição da dualidade estrutural na formação conformada à acumulação capitalista?. Cad. Pesq. Pensamento Educacional, v.5, p.13-32, 2010.

FRIGOTTO, G. Os circuitos da história e o balanço da educação no Brasil na primeira década do século XXI. Rev. Bras. Educ., v.16. n.46, 2011.

KENSKI, V.M. Educação e tecnologias: o novo ritmo da informação. Campinas: Papirus, 2012.

MORAN, J.M.; MASSETO, M.T.; BEHRENS, M.A. Novas tecnologias e mediação pedagógica. Campinas: Papirus, 2013. 